\title{
The Effectiveness of the Flipped Classroom in a Teacher Training Context
}

\author{
Saïd Boubih ${ }^{1,2 *}$, Anouar Aidoun², Mustafa El Alaoui ${ }^{2}$, Rachid Janati Idrissi ${ }^{2}$ \\ ${ }^{1}$ Regional Centre for Education and Training Professions, Avenue Moulay Abdelaziz, Souani, Tangier, Morocco \\ ${ }^{2}$ École Normale Supérieure (ENS), Abdelmalek ESSAADI University, Avenue Hassan II, Martil, Morocco
}

Received August 8, 2020; Revised September 30, 2020; Accepted October 19, 2020

\section{Cite This Paper in the following Citation Styles}

(a): [1] Saïd Boubih, Anouar Aidoun, Mustafa El Alaoui, Rachid Janati Idrissi , "The Effectiveness of the Flipped Classroom in a Teacher Training Context," Universal Journal of Educational Research, Vol. 8, No. 11B, pp. 6061 - 6071, 2020. DOI: 10.13189/ujer.2020.082242.

(b): Saïd Boubih, Anouar Aidoun, Mustafa El Alaoui, Rachid Janati Idrissi (2020). The Effectiveness of the Flipped Classroom in a Teacher Training Context. Universal Journal of Educational Research, 8(11B), 6061 - 6071. DOI: 10.13189/ujer.2020.082242.

Copyright $\subseteq 2020$ by authors, all rights reserved. Authors agree that this article remains permanently open access under the terms of the Creative Commons Attribution License 4.0 International License

\begin{abstract}
The flipped classroom is a model of teaching in which activities traditionally conducted in the classroom become homework activities, and activities that normally constitute homework become classroom activities. This pedagogical model has been proposed in several studies as an alternative educational approach to conventional methods, but its effectiveness in improving outcomes is disputed. To test the effectiveness of this model, we followed a semi-experimental approach, using a pre- and post-test. A group of future life and earth science teachers from an experimental classroom $(n=62)$ was trained using the flipped classroom approach. However, the trainees in the control class $(n=62)$ followed traditional teaching. Pre- and post-test results were analyzed using the t-test to assess the effectiveness of this teaching model. There were no significant differences between the two groups in the pre-test, indicating that the two groups were equivalent prior to our intervention. However, a statistically significant difference was recorded in the post-test in favor of the experimental group members, particularly for questions related to knowledge manipulation. For the questions assessing the degree of knowledge acquisition, we found no significant difference between the two groups. We could therefore conclude that the integration of the flipped classroom in a training situation for future teachers has a positive effect on the improvement of learning performance. This approach can also serve as a means of varying our teaching practices and benefiting from the advantages of distance learning.
\end{abstract}

Keywords Flipped Classroom, Reverse Classroom, Blended Learning, Future Teachers, Educational Technology

\section{Introduction}

To cope with the shortage of teachers in the Moroccan education system, the Ministry of National Education has launched a massive operation to recruit contract teachers, and a considerable effort has made it possible to recruit 70,000 teachers in less than four years [1]. However, the time devoted to training these future teachers in the Regional Centers for Education and Training Professions (RCETP) generally lasts only seven months, which is very insufficient to acquire the various skills covered by the modules taught [2]. Indeed, a training curriculum for the teaching of Life and Earth Sciences (LES) is not reducible to disciplinary contents but must propose training situations to apply the didactic and pedagogical concepts [3].

To optimize the use of training time and to distribute the workload between presence and distance, a hybrid device can be proposed [4, 5]. This device combines the advantages of traditional classrooms and distance learning: learners retain the possibility of interpersonal interaction with the teacher and their peers, while being able to pursue independent learning at their own pace without the 
limitations of time and place [6].

Several benefits have been attributed to the flipped classroom as a blended learning model, including improved learning performance, learner satisfaction and engagement, learning flexibility, better use of class time, positive student perception and increased students' interaction $[7,8]$. However, the articles that present the benefits of flipped classroom pedagogy rely primarily on subjective assessment (from the teacher's perspective) of the outcomes of the flipped classroom [9]. Indeed, there are relatively few studies on the effectiveness of the flipped model $[8,10]$. Therefore, before inviting trainers to model and implement reverse education in teacher preparation curricula $[8,11]$, more research is needed in the area of reverse education at all educational levels and in all subjects, including teacher education [8]. It is within this framework that this study is being carried out. Its objective is to test the effectiveness of this pedagogical approach in the training of trainee teachers.

In our study, we will try to answer the following research questions:

- Did the trainee teachers in the flipped classroom show greater learning gains than the trainees in the traditional classroom?

- If so, what skills were improved?

\section{Literature Review}

\subsection{Theoretical Background}

\subsubsection{Concept of the Flipped Classroom}

The flipped classroom is a model of teaching in which activities traditionally conducted in the classroom become homework activities, and activities that normally constitute homework become classroom activities [12]. To implement this practice, students are invited to prepare the theoretical lesson at home based on activities proposed by their teachers in digital format (videos, texts, didactic images, website, etc.) or in literal format (textbook, handout, etc.) to acquire basic knowledge that will be mobilized in the classroom through group work activities $[9,13,14]$. Thus, instead of focusing on the presentation of information, teachers use class time to focus on important gaps in learners' understanding and help them make connections between the information they have gathered before the class [8].

Bishop \& Verleger [15] take a more restrictive view of the flipped classroom. For these two researchers, any model that does not use closed-ended videos and quizzes or hands-on exercises as out-of-class activities is not considered a flipped classroom.

\subsubsection{History of the Flipped Classroom}

Historically, it was Erik Mazur, Professor of Physics at Harvard in the United States, who is considered to be the precursor of the flipped classroom in the 1990s [16, 17]. In his book "Peer Instruction: A User's Manual" on peer work, Mazur described the technique of "flipped classroom" without using the term. The latter was introduced by Lage and colleagues in the 2000s. They clarified that flipped classroom means that events that traditionally took place inside the classroom now take place outside the classroom and vice versa [6, 17-19]

The term "flipped classroom" gained popularity only after the work of Bergmann and Sams [6, 13]. According to these two chemistry professors, lectures are necessary to convey content, but experiential learning is more effective in building and solidifying knowledge. The podcasting they have adopted has allowed them to reconfigure their chemistry courses, and class time is exclusively reserved for lab activities, demonstrations, individual assistance, and small group tutoring [20]. Thus, the slogan "Lectures at Home and Homework in Class" was launched [17].

Salman Khan also promoted this teaching method in March 2011 at a conference "TED: Technology, Entertainment and Design" where he proposed the use of his educational videos to flipped classes [21, 22]. Khan is a mathematician who started as early as 2006 to make and post videos on YouTube to help his young cousin in mathematics at a distance [13]. Following the success of these videos, Salman Khan, with the financial support of Bill Gates, created the Khan Academy, a non-profit educational organization that now offers more than 5,000 course videos in several subjects [13]. These videos are accessible to one million students per month, with up to 200,000 videos viewed by students online each day [23]. The audience of the Khan Academy increased in 2020 due to containment caused by the Covid pandemic19 [24].

\subsubsection{Theoretical Foundations of the Flipped Classroom}

The flipped classroom is an original model that is based on old teaching concepts, facilitates students' learning [13]. It is a unique combination of learning theories that were once considered incompatible [15]. Out-of-class activities derive from direct teaching methods based on behaviorist principles, whereas classroom activities are based on the principles of constructivism [15]. According to Green [23], the processes and mechanisms underlying the implementation of flipped classrooms derive from social constructivism. Nizet [25] agrees with this idea and states that:

The flipped classroom is similar to other well-known pedagogical methods such as the problem-based approach, self-learning or tutoring; it is also clearly based on differentiated pedagogy, and to some extent on principles of socio-constructivism. The importance given to the co-construction of knowledge by students and the importance of dialogue with the teacher and peers in the classroom bear witness to this. (p. viii).

The flipped classroom places an important place on the accomplishment of tasks such as writing texts, making mental maps, solving problems, etc. The accomplishment of these tasks is essential for learning and results show that 
there is a close relationship between the students' academic level and the level of mastery of these task [26]. In the flipped classroom, tasks can be focused on the four levels of students' engagement: passive, active, interactive, and constructive [27]. The activities that fall under the passive level (listening to the capsule) and the active level (answering the quiz or filling out a questionnaire) take place in the home. In the classroom, the interactive level (collaboration) and the constructive level (mobilizing knowledge to build a network around the concepts and notions to be learned) are favored. According to Chi [27], interactive activities are most likely to be better than constructive activities, which, in turn, might be better than active activities, which are better than passivity.

\subsubsection{Skills Assessed in the LES Tests}

LES teachers trained at RCETPs are intended to teach in the secondary cycle. They will be required to propose tests to their students that are in accordance with the official instructions [28]. According to these instructions, the tests must be composed of two parts belonging to two skill areas (SA):

- $\quad$ The first part entitled "Knowledge Restitution" (KR). It aims to assess the learner's degree of mastery of knowledge using:

- $\quad$ multiple choice questions;

- $\quad$ alternative questions (true or false);

- matching questions;

- $\quad$ serialization and classification questions;

- $\quad$ short answer questions (defining; captioning a diagram or graph; knowing theories, laws, scientific terms, facts, signs ...).

- $\quad$ The second part, entitled "Scientific Reasoning, Graphic and Written Communication" (RSCGE), is composed of exercises based on document analysis. Its purpose is to assess the learner's level of mastery of the skills and abilities presented in Appendix 1.

To accustom our trainees to these guidelines, the tests they take to validate the Internal Geodynamics module (subject of this study) also include these two parts.

\subsection{Previous Studies}

In reviewing 44 peer-reviewed articles published between 2000 and 2015 on the application of the flipped classroom in higher education, Guilbault \& Viau-Guay [29] noted a difference in results on the effectiveness of this strategy in improving students' learning. Indeed, some research has recorded a positive impact of the flipped classroom on academic results [30-38], while others have not recorded this positive impact [39-42]. All these researches compare the results of the students, using the "test group/control group" design.

This difference in results between these different studies could be explained by the nature of the competency assessed in the different tests. For example, while there was no variation in the learning of conceptual and declarative content, the results for open-ended questions or those requiring problem-solving skills show improvement [29].

For our part, we reviewed studies conducted in a teacher education context and published between 2016 and 2020. There are eight of these studies, and most of them used questionnaires to survey trainees' opinions and perceptions regarding the flipped classroom technique [6, 8, 11, 43-45]. Only two studies used tests to measure the influence of this pedagogical approach on improving learning outcomes using a semi-experimental approach with a pre-test and a post-test [10], or using the 'control group - experimental group' design and compare the results obtained by the students in the evaluation tests [46].

All of these studies attributed positive effects to the flipped classroom such as the fact that lessons taught in the flipped classroom model were interactive and fun [8, 43], an overall positive perception of teaching in the flipped classroom [10, 43, 46], an improvement of trainees' performance in terms of self-learning, interaction and team collaboration [11, 44] and an improvement in learning outcomes $[10,46]$.

\section{Research Methodology and Protocol}

\subsection{Methodology and Sample}

To assess the effect of using the flipped classroom on learning improvement, we used a semi-experimental approach, with a pre-test and a post-test. The semi-experimental approach replaces the design of real experiments when the allocation of participants (between experimental and control groups) is based on the principle of self-selection and/or on the choice of administrators [47]. The study was carried out among 124 trainee teachers in life and earth sciences (LES), continuing their training at the RCETP of Tangier (Morocco). They belonged to two academic years and were divided into classes by the RCETP administration. This classes are randomly assigned to a control and an experimental group, as shown in Table 1 .

Table 1. Distribution of trainee teachers between control and experimental groups

\begin{tabular}{|c|c|c|}
\hline Academic year & Control Group & Experimental Group \\
\hline $2018 / 2019$ & 30 & 31 \\
\hline $2019 / 2020$ & 32 & 31 \\
\hline Total & 62 & 62 \\
\hline
\end{tabular}

There are no significant differences between the two groups in terms of gender, age and degrees obtained by trainees. It should be noted, however, that the proportion of trainee teachers with a university background in geology, the discipline evaluated in this study, is very low for both groups (Table 2). 
Table 2. Characteristics of the control and experimental groups

\begin{tabular}{|c|c|c|c|}
\hline \multicolumn{2}{|c|}{} & Control Group & $\begin{array}{c}\text { Experimental } \\
\text { Group }\end{array}$ \\
\hline \multicolumn{2}{|c|}{ Headcount } & 30 & 31 \\
\hline \multirow{2}{*}{ Sex } & Female & $56,7 \%$ & $67,7 \%$ \\
\cline { 2 - 4 } & Male & $43,3 \%$ & $32,3 \%$ \\
\hline \multirow{2}{|c|}{ Age } & $\begin{array}{c}\text { Between } 21 \text { and } \\
40 \text { years }\end{array}$ & $\begin{array}{c}\text { Between } 22 \text { and } 34 \\
\text { years }\end{array}$ \\
\hline \multirow{2}{*}{$\begin{array}{c}\text { University } \\
\text { Degree }\end{array}$} & PhD & $3,3 \%$ & $3,2 \%$ \\
\cline { 2 - 4 } & Master & $36,7 \%$ & $35,5 \%$ \\
\hline \multirow{4}{*}{\begin{tabular}{c} 
Specialty \\
\cline { 2 - 4 }
\end{tabular}} & License & $60,0 \%$ & $61,3 \%$ \\
\cline { 2 - 4 } & Biology & $76,7 \%$ & $87,1 \%$ \\
\cline { 2 - 4 } & Geology & $3,3 \%$ & $0,0 \%$ \\
\hline
\end{tabular}

\subsection{Experimental Process}

\subsubsection{Duration of the Experiment and Themes Studied}

The study concerned the module of internal geodynamics, one of the modules of the first semester of training of future teachers of Life and Earth Sciences. This module is composed of six knowledge areas (KAs) for an hourly volume of thirty hours, at a rate of three hours per week. These areas are:

- $\quad$ Continental drift (KA I);

- $\quad$ Plate tectonics (KA II);

- $\quad$ Magmatism and Magmatic Rocks (KA III);

- The relationship between volcanism and plate tectonics (KA IV);

- The relationship between earthquakes and plate tectonics (KA V);

- Metamorphism and metamorphic rocks (KA VI).

This study was repeated twice, in two successive academic years, to increase the size of our sample.

\subsubsection{Research Tools}

At the beginning of the experiment, an assessment tool was administered to students in the control and experimental groups, which is the pre-test phase. It is composed of 30 elements spread over 5 exercises numbered from I to $\mathrm{V}$ (Appendix 2). When developing this tool, we ensured that the two skill areas (SA) were given equal weight (Table 3 ).

Table 3. Specification table of the evaluation tool

\begin{tabular}{|c|c|c|c|c|}
\hline KA SA & KR & SRGWC & Total (\%) & $\begin{array}{c}\text { KA } \\
\text { Scores }\end{array}$ \\
\cline { 1 - 4 } KA I & $2,5 \%$ & $0 \%$ & $2,5 \%$ & 0,5 pt. \\
\hline KA II & $12,5 \%$ & $18,75 \%$ & $31,25 \%$ & 6,25 pts \\
\hline KA III & $17,5 \%$ & $7,5 \%$ & $25 \%$ & 5 pts \\
\hline KA IV & $5 \%$ & $0 \%$ & $5 \%$ & 1 pt. \\
\hline KA V & $0 \%$ & $15 \%$ & $15 \%$ & 3 pts \\
\hline KA VI & $12,5 \%$ & $8,75 \%$ & $21,25 \%$ & 4,25 pts \\
\hline Total (\%) & $50 \%$ & $50 \%$ & \multirow{2}{*}{$100 \%$} & 20 pts \\
\hline SA scores & 10 pts & 10 pts & & \\
\cline { 1 - 2 }
\end{tabular}

At the end of the proposed pedagogical activities, the post-test was administered to both groups. It is the same assessment tool as the one used in the pre-test phase. The trainee teachers were informed that the test was not scored and that it would be used for research purposes only.

\subsubsection{Checking the Reliability of the Assessment Tool}

We used Cronbach's alpha coefficient to measure the reliability of the internal consistency of our assessment tool [48]. It is the most widely used statistical test for measuring internal consistency in research [49]. From a logistical point of view, measuring the reliability of internal consistency is simple because it does not require administering the test twice or having two forms of testing [50].

Before administering our assessment tool to both groups, we tested it on a pilot group of twenty trainees randomly selected from the 2017/2018 graduating class. The Cronbach's alpha value measured was 0.718 . According to the Cronbach's alpha interpretation scale (Table 4), our assessment tool has a respectable reliability.

Table 4. Cronbach's alpha interpretation scale [51]

\begin{tabular}{|c|c|}
\hline Alpha Coefficient & Implied Reliability \\
\hline Less than 0.60 & Unacceptable \\
\hline Between 0.60 and 0.65 & Undesirable \\
\hline Between 0,65 and 0,70 & minimally acceptable \\
\hline Between 0,70 and 0,80 & Respectable \\
\hline Between 0,80 and 0,90 & very good \\
\hline More than 0.90 & consider shortening the scale \\
\hline
\end{tabular}

\subsubsection{Facilitation of Teaching/Learning Activities}

To animate the training/learning activities of the internal geodynamics module, the trainer, who is one of the researchers, followed two pedagogical approaches: the so-called "traditional" approach with the control group, and the flipped classroom approach with the experimental group.

The traditional approach was mainly based on weekly three-hour lectures presented using power point. Trainees can follow in a course material distributed at the beginning of each session and can intervene with questions to ask for further explanations. Under this approach, the trainees' first contact with the course was in the classroom and application exercises were rarely done.

In the flipped classroom model, the trainee is asked to perform a series of tasks at home and others in the classroom. At home, the trainee is invited to read the course in PDF format, which they receive on an online platform called Padlet. It is a collaborative wall that allows many resources to be grouped in one place and provides a comment area for trainees to communicate with each other and with the instructor. Afterwards, he or she must view 
one or more video clips. These are narrated PowerPoint presentations, produced by the author using screen capture and video editing software. Sometimes existing videos on YouTube have been used to vary the presentations and keep trainees engaged. For viewing and statistical data, the videos are hosted on the Edpuzzle website. This is an educational platform for sharing videos. The strength of this platform is that it provides information on how learners interact with the video, such as how many times they have watched each section of the video and how long it takes them to go through it. Edpuzzle also allows to integrate quizzes into the videos and collect learners' answers.

In class, the session is divided into two periods. The first consists of collaborative work and regulation of learning: a pair of trainees, selected in advance, present the essential ideas of the theme studied and the trainee teachers, working in groups, discuss these concepts and establish a synthesis scheme. The second period is a period of knowledge application and consists of doing exercises and solving problems related to the theme studied.

The two groups were given a single practical session on the identification of magmatic rocks.

\subsection{Statistical Methods}

Pre- and post-test results were analyzed using the t-test for independent samples (Student's test). This test is a statistical tool used to compare the mean values of two groups [52]. In this test, two assumptions were made:

- The null hypothesis (H0) that there is no difference between the means of the two groups;

- The alternative hypothesis (H1) that there is a difference between the two means.

The null hypothesis is rejected when the degree of significance (p-value) is less than 0.05 (commonly chosen alpha value).

The effect of the nature of the skills assessed on the trainee's performance is determined using Tukey's HSD test. This is a multiple comparison test that can be used to determine whether the means are different from each other in an analysis of variance.

All these statistical analyses were performed using SPSS version 20.0 software.

\section{Results and Discussion}

\subsection{Verification of the Equivalence of the Control and the Experimental Groups}

The equivalence of these two groups is verified by comparing the scores obtained by the trainees during the pre-test. The results obtained are presented in Table 5.
Table 5. T-test results for the mean scores of the control and experimental groups during the pre-test

\begin{tabular}{|c|c|c|}
\hline Group & Control & Experimental \\
\hline Sample Size & 62 & 62 \\
\hline Average score $(\mathrm{m})$ & 5,55 & 4,65 \\
\hline Standard deviation $(\sigma)$ & 2,99 & 2,66 \\
\hline $\mathrm{ddl}$ & \multicolumn{2}{|c|}{122} \\
\hline $\mathrm{T}$ & \multicolumn{2}{|c|}{0,740} \\
\hline Level of significance & \multicolumn{2}{|c|}{ No difference } \\
\hline interpretation & \multicolumn{2}{|c|}{} \\
\hline
\end{tabular}

Based on these results, the average scores for both groups are below 10 out of 20 . There is no difference between the two groups because the t-value (0.087) exceeds the chosen alpha value $(\alpha=0.05)$. Thus, the two groups in the study are equal before our intervention. This equivalence can be explained by the fact that most of the trainees are biology graduates and that their distribution into classes was randomized by the RCETP administration.

\subsection{Effect of the Flipped Classroom on Trainees' Post-test Scores}

To test whether there was a statistically significant difference in the mean scores of trainees in the two groups at post-test, we compared them using the t-test. The results are presented in Table 6.

Table 6. T-test results for the mean scores of the control and experimental groups during the post-test

\begin{tabular}{|c|c|c|}
\hline Group & Control & Experimental \\
\hline Sample Size & 62 & 62 \\
\hline Average score $(\mathrm{m})$ & 10,76 & 12,58 \\
\hline Standard deviation $(\sigma)$ & 2,48 & 1,93 \\
\hline $\mathrm{ddl}$ & \multicolumn{2}{|c|}{122} \\
\hline $\mathrm{t}$ & \multicolumn{2}{|c|}{0,0000006} \\
\hline Level of significance & There is a significant difference \\
\hline interpretation & \multicolumn{2}{|c|}{}
\end{tabular}

The difference in scores recorded between the two groups at the post-test is approximately 1.82 points in favor of the experimental group. This difference is significant because the significance level is well below 0.05 . It can therefore be assumed that after the end of the training, the trainees in the experimental group performed statistically better than the trainees in the control group.

To assess the significance of the difference between the two groups and to demonstrate whether it is not due to hazard, we calculated the eta squared ( $\eta 2)$. This is a parameter that allows us to estimate the effect size of the independent variable (flipped classroom) on the dependent variable (trainee learning). It is calculated by the following equation:

$$
\eta^{2}=\eta^{2}=t^{2} /\left(t^{2}+d d l\right)=(4,749)^{2} /\left((4,749)^{2}+122\right)=0,156
$$


Using the guidelines developed by Cohen [52] to interpret the values of the eta squared (Table 7), we can deduce that the flipped classroom, as we applied it with our trainees, has a large effect on the results obtained by the trainees in the post-test.

Table 7. Interpretation of the values of the eta squared. (from: https://bit.ly/2Y8FXDB)

\begin{tabular}{|c|c|}
\hline eta squared values & Interpretation \\
\hline Around 0.01 & Small size effect \\
\hline Around 0,06 & Medium size effect \\
\hline Around 0.14 and over & Large size effect \\
\hline
\end{tabular}

We could therefore conclude that the integration of the flipped classroom in a training situation gave better results than the classical method. This result is in line with the studies of González-Gómez et al, [46] and Kurt [10] who showed that there is an improvement in the results among trainee teachers after the implementation of the flipped classroom method as a training method. This improvement can be attributed to the positive effects of this didactic approach and in particular to those previously cited by Akçayır \& Akçayır [7] and Graziano [8].

The flipped classroom, as a blended learning model, provides trainees with a continuous interactive environment. Thus, and through its greater differentiation of instruction, this approach enhances students' motivation and facilitates learning [10]. The instructional videos used have also proven to be effective. They allow trainees to learn at their own pace: they can pause, rewind and review the content of the instruction, thus deciding how much information they want to assimilate over a period of time [6]. These videos also stimulate more than one sense in the learner by integrating images, graphics, video clips and sound effects and help to remember, understand, assimilate, and make learning more enjoyable [53].

The self-corrected quizzes that trainees receive online also contribute to improved results. They enable trainees to engage in viewing videos and reading course materials. According to Karpicke \& Roediger [54], a passive learner does not learn, whereas learning is optimal when the learner alternates learning with immediate and repeated testing of his/her knowledge. These quizzes are also a kind of home practice, and trainees can self-assess and identify concepts and notions that need to be discussed face-to-face.

The saving of time in the classroom, thanks to the trainees' autonomous work, is also a parameter that has contributed to the improvement of their learning. In fact, this freed up time has allowed us to plan remediation times and to carry out tasks that improve learning [26]. We also used this time to organize activities aimed to develop some professional skills such as modeling, developing posters and mind maps, and improving the quality of presentations.

The engagement of the trainees is also an essential parameter in the improvement of learning. In fact, they fully adhered to carrying out the activities at home. This engagement is essential for the acquisition of explicit knowledge [26].

\subsection{Skills Improved by the Flipped Classroom}

To answer the second research question, we compared the post-test scores of trainees in the two groups according to skill areas. The results are shown in Table 8 .

Table 8. Mean values \pm standard errors of scores by skill area

\begin{tabular}{|c|c|c|c|}
\hline $\begin{array}{c}\text { Skill } \\
\text { Areas }\end{array}$ & $\begin{array}{c}\text { Control } \\
\text { Group }\end{array}$ & $\begin{array}{c}\text { Experimental } \\
\text { Group }\end{array}$ & Deviation \\
\hline KR & $5,45 \pm 0,24$ & $6,08 \pm 0,20$ & 0,63 \\
\hline SRGWC & $4,77 \pm 0,28$ & $6,68 \pm 0,23$ & 1,91 \\
\hline
\end{tabular}

We note that the scores obtained by trainees in the experimental group are better than those of trainees in the control group. However, the difference in scores between the two groups is much greater in the "scientific reasoning, graphic and written communication" section.

By detailing this study, and comparing the results according to knowledge areas, we obtain the results in Table 9.

Table 9. Mean values \pm standard errors of scores obtained for each area of knowledge according to skill areas

\begin{tabular}{|c|c|c|c|c|c|}
\hline \multicolumn{2}{|c|}{} & \multicolumn{4}{|c|}{ Skill Areas } \\
\cline { 3 - 6 } \multicolumn{2}{|c|}{} & \multicolumn{2}{|c|}{ KR } & \multicolumn{2}{c|}{ SRGWC } \\
\cline { 3 - 6 } & Control Group & Experimental Group & Control Group & Experimental Group \\
\hline \multirow{4}{*}{$\begin{array}{c}\text { Knowledge } \\
\text { areas }\end{array}$} & KA I & $0,08 \mathrm{a} \pm 0,03$ & $0,10 \mathrm{a} \pm 0,04$ & - & - \\
\cline { 2 - 6 } & KA II & $1,92 \mathrm{a} \pm 0,10$ & $2,05 \mathrm{a} \pm 0,09$ & $1,41 \mathrm{a} \pm 0,16$ & $2,13 \mathrm{~b} \pm 0,14$ \\
\cline { 2 - 6 } & KA III & $1,10 \mathrm{a} \pm 0,12$ & $1,32 \mathrm{a} \pm 0,10$ & $1,04 \mathrm{a} \pm 0,10$ & $1,23 \mathrm{a} \pm 0,07$ \\
\cline { 2 - 6 } & KA IV & $0,48 \mathrm{a} \pm 0,07$ & $0,69 \mathrm{~b} \pm 0,05$ & & $2,02 \mathrm{~b} \pm 0,14$ \\
\cline { 2 - 6 } & KA V & & & $1,32 \mathrm{a} \pm 0,15$ & $1,30 \mathrm{~b} \pm 0,06$ \\
\hline
\end{tabular}

The mean values with their standard errors followed by the same letters do not differ significantly (Tukey's HSD test at $\alpha \leq 0,05$ ). 
These results show that the improvement in results for the skill area "knowledge restitution" is recorded in only one knowledge area. On the other hand, this improvement is recorded in three areas of knowledge for the part "scientific reasoning and graphic and written communication". In the latter part, the only area that constitutes the exception is magmatism and magmatic rocks. Indeed, answering the questions asked in this field requires the mobilization of the knowledge seen in the lab experiments to identify the rocks. Both groups benefited from this session.

Our study confirms that the positive effects of the flipped classroom technique are recorded especially in activities requiring high cognitive skills and not a simple restitution of knowledge. It is consistent with studies that have found that while the learning of conceptual and declarative content did not change after the class was reversed, results for open-ended questions or those requiring problem-solving skills improved [29]. According to Guilbault \& Viau-Guay [29], and in contrast to lectures, the flipped classroom allows students to reach the final levels of intellectual skills in Bloom's revised taxonomy, namely creation, evaluation, analysis, and application. Indeed, in the flipped classroom, activities that target low-level cognitive skills are conducted at home, while classroom time is devoted to learning activities that target higher-level skills.

\section{Conclusion and Recommendations}

Given the basic training of trainee teachers, most of them suffer from many difficulties. Diagnosing these difficulties and proposing remedial activities is not always possible in RCETPs because of the limited time allocated to each module. Thanks to the flipped classroom technique, the independent work of the trainees before attending classes freed up time that was used to integrate active learning activities. This had a positive effect on the results of the trainees in this class compared to those in the traditional class. Thus, the answer to the first research question is affirmative because the flipped classroom system is effective in improving the learning of trainee teachers. For the second research question, this study showed that the positive effect of the flipped classroom was particularly noted in questions that assess the learner's ability to manipulate knowledge to answer problems.

It is certainly too early to generalize our assertions about the success of our experiment and the validity of our research findings. However, the encouraging results we have obtained allow us to invite other teachers to test this approach, especially since the majority of them applied distance education during the period of lockdown due to the covid-19 pandemic. Hybrid devices, such as the flipped classroom, will make it possible to benefit from the advantages of distance education since, from a pedagogical point of view, the simple return to the regular education, after the covid-19 crisis, will be experienced as a regression [55].

\section{List of Abbreviations}

KA: Knowledge Areas

KR: Knowledge Restitution

LES: Life and Earth Sciences

RCETP: Regional Centre For Education and Training Professions

SA: Skill Areas

SRGWC: Scientific Reasoning, Graphic and Written Communication

\section{Appendices}

Appendix 1: Abilities and skills assessed in the "Scientific Reasoning, Graphic and Written Communication" section:

- Identifying and formulating a scientific problem;

- Use knowledge, select, and organize information in relation to the subject of study;

- $\quad$ Relate information with the acquired knowledge to solve the scientific problem posed;

- $\quad$ To propose and formulate one or more hypotheses in relation to the scientific problem;

- To mobilize information to solve the scientific problem posed or to explain phenomena, object of study;

- To propose the adequate tools to verify the hypothesis;

- $\quad$ To describe and analyze scientific data;

- Compare and explain/interpret results;

- $\quad$ Deduce and generalize;

- Use principles, laws, models to explain/interpret phenomena and scientific data;

- To make a synthesis of information and data in a text or diagram; - To express an opinion and to argue it;

- To represent a biological or geological structure or phenomenon by a diagram;

- Translate numerical data into tabular, graphical or text form;

- Create a block diagram;

- $\quad$ Create a synthesis diagram; 


\section{Appendix 2: Organization of the assessment tool (pre-test and post-test)}

\begin{tabular}{|c|c|c|c|}
\hline \multicolumn{4}{|c|}{ Part I: Knowledge restitution } \\
\hline Domains & Item & Question types & Scores \\
\hline Continental drift & II.1 & Multiple-choice questions & 0,5 pt. \\
\hline \multirow{5}{*}{ Plate Tectonics } & II. 2 & \multirow{5}{*}{ Multiple-choice questions } & 0,5 pt. \\
\hline & II.3 & & 0,5 pt. \\
\hline & II.4 & & 0,5 pt. \\
\hline & II.5 & & $0,5 \mathrm{pt}$. \\
\hline & II.6 & & 0,5 pt. \\
\hline \multirow{7}{*}{ Magmatism and magmatic rocks } & I. 1 & \multirow{7}{*}{ Short answer questions } & 0,5 pt. \\
\hline & II.7 & & 0,5 pt. \\
\hline & II.8 & & $0,5 \mathrm{pt}$. \\
\hline & II.9 & & 0,5 pt. \\
\hline & II.12 & & 0,5 pt. \\
\hline & II.14 & & 0,5 pt. \\
\hline & II.16 & & $0,5 \mathrm{pt}$. \\
\hline \multirow{2}{*}{ Volcanism and plate tectonics } & II.17 & \multirow{2}{*}{ Multiple-choice questions } & 0,5 pt. \\
\hline & II.18 & & 0,5 pt. \\
\hline $\begin{array}{l}\text { Earthquake and plate tectonics } \\
\text { relationship }\end{array}$ & & $\frac{-}{-}$ & \\
\hline \multirow{5}{*}{$\begin{array}{l}\text { Metamorphism and metamorphic } \\
\text { rocks }\end{array}$} & I.2 & \multirow{5}{*}{ Short answer questions } & 0,5 pt. \\
\hline & II.10 & & 0,5 pt. \\
\hline & II.11 & & $0,5 \mathrm{pt}$ \\
\hline & II.13 & & 0,5 pt. \\
\hline & II.15 & & 0,5 pt. \\
\hline \multicolumn{4}{|c|}{ Part II: Scientific Reasoning, Graphic and Written Communication } \\
\hline Domains & Item & Assessed capabilities & Notes \\
\hline \multicolumn{4}{|l|}{ Continental drift } \\
\hline \multirow{3}{*}{ Plate Tectonics } & V.1 & Select information related to the topic & 0,75 pt. \\
\hline & V.III & $\begin{array}{c}\text { Linking information with what has been learned to solve the scientific } \\
\text { problem posed }\end{array}$ & 1 pt. \\
\hline & V.4 & To carry out a synthesis of information and data in the form of text & 2 pts \\
\hline \multirow{3}{*}{ Magmatism and magmatic rocks } & III.1 & \multirow{3}{*}{$\begin{array}{l}\text { Using knowledge, selecting, and organizing information concerning the } \\
\text { subject of study }\end{array}$} & 0,5 pt. \\
\hline & III.2 & & 0,5 pt. \\
\hline & III.3 & & 0,5 pt. \\
\hline \multicolumn{4}{|l|}{ Volcanism and plate tectonics } \\
\hline \multirow{2}{*}{$\begin{array}{l}\text { Earthquake and plate tectonics } \\
\text { relationship }\end{array}$} & IV.1 & Representing a geological phenomenon by a diagram & 1 pt. \\
\hline & IV.2 & Solving a problem using a known formula & $2 \mathrm{pts}$ \\
\hline \multirow{2}{*}{$\begin{array}{l}\text { Metamorphism and metamorphic } \\
\text { rocks }\end{array}$} & III.4 & $\begin{array}{l}\text { Using knowledge, selecting, and organizing information concerning the } \\
\text { subject of study }\end{array}$ & 0,5 pt. \\
\hline & V.2 & $\begin{array}{l}\text { - Translating numerical data in tabular form } \\
\text { - Interpreting results }\end{array}$ & $1,25 \mathrm{p}$. \\
\hline
\end{tabular}




\section{REFERENCES}

[1] MAP, "La formation des enseignants, un projet majeur de la réforme du système éducatif." http://www.maroc.ma/fr/actu alites/la-formation-des-enseignants-un-projet-majeur-de-lareforme-du-systeme-educatif (accessed 29/05/2020).

[2] M. El Hajji, R. D. El Bouzaidi, H. Douzi, and E. H. Khouya, "New Blended Learning Strategy Based on Flipped-Learning for Vocational Work-Linked Training," Journal of Education and Practice, vol. 7, no. 36, pp. 126-130, 2016. https://www.semanticscholar.org/paper/Ne w-Blended-Learning-Strategy-Based-on-for-Training-HajjiBouzaidi/0ac5627bec05f1071b2951e3377e352d78b127c4

[3] M. Madrane, M. Khaldi, and M. Talbi, "Un système de formation à l'enseignement des sciences dans le contexte éducatif marocain : des conditions pour une évolution possible," Contextes et Didactiques (3), 2009. URL : https://www.contextesetdidactiques.com/815.

[4] P. Fadde and P. Vu, "Blended online learning: Benefits, challenges and misconceptions," in Online learning: Common misconceptions, benefits and challenges, P. R. Lowenthal, C. S. York, and J. C. Richardson Eds. Hauppauge, NY: Nova Science Publishers, 2014, pp. 33-48.

[5] D. Peraya, B. Charlier, and N. Deschryver, "Une première approche de l'hybridation," Education et formation, no. e-301, pp. 15-34, 2014. URL: https://archive-ouverte.unige. ch/unige:37049/ATTACHMENT01

[6] Y. Y. Lee and K. I. Martin, "The flipped classroom in ESL teacher education: An example from CALL," Education and Information Technologies, 2019, doi: 10.1007/s10639-01910082-6.

[7] G. Akçayır and M. Akçayır, "The flipped classroom: A review of its advantages and challenges," Computers and Education, vol. 126, no. July, pp. 334-345, 2018, doi: 10.1016/j.compedu.2018.07.021.

[8] K. J. Graziano, "Peer Teaching in a Flipped Teacher Education Classroom," TechTrends, vol. 61, no. 2, pp. 121-129, 2016, doi: 10.1007/s11528-016-0077-9.

[9] A. Manon, "Quels sont les effets de la classe inversée sur les performances des élèves?," Master en métiers de l'enseignement, de l'éducation et de la formation, Ecole Supérieure du professorat et de l'éducation, Université Savoie Mont Blanc, 2016. URL: https://pdfs.semanticschol ar.org/3609/a5a245d319641787a4822919dc11f5df726b.pdf ?_ga $=2.68439505 .1184677971 .1596989644-634844388.15$ 96896231\&_gac $=1.118946939 .1596989644 . C j 0 K C Q j w v b 7$ 5BRD1ARIsAP6LcqtIn5tp1kI92CrzM_NuoQ5DR8qriPOcuT2SGjBPbT0Z1FiM55fwrsaAjP6EALw_wcB

[10] G. Kurt, "Implementing the flipped classroom in teacher education: Evidence from Turkey," Educational Technology and Society, vol. 20, no. 1, pp. 211-221, 2017. URL: https://pdfs.semanticscholar.org/d0ce/1a027906c5796e00fd 893885b26a276d2b5d.pdf?_ga=2.23455482.1184677971.1 596989644-634844388.1596896231\&_gac $=1.119920122 .1$ 596989644.Cj0KCQjwvb75BRD1ARIsAP6LcqtIn5tp1kI92 CrzM_NuoQ5DR8qriPOc-uT2SGjBPbT0Z1FiM55fwrsaAj P6EALw_wcB
[11] D. González-Gómez, J. S. Jeong, and F. Cañada-Cañada, "Enhancing science self-efficacy and attitudes of Pre-Service Teachers (PST) through a flipped classroom learning environment," Interactive Learning Environments, pp. 1-12, 2019, doi: 10.1080/10494820.2019.1696843.

[12] J. Bergmann and A. Sams, Flip Your Classroom: Reach Every Student in Every Class Every Day. Arlington, VA: International Society for Technology in education, 2012.

[13] H. Dufour, "La classe inversée," TECHNOLOGIE 193, pp. 44-47, 2014. URL: https://eduscol.education.fr/sti/sites/edu scol.education.fr.sti/files/ressources/techniques/6508/6508193-p44.pdf

[14] V. Faillet, "La pédagogie inversée : recherche sur la pratique de la classe inversée au lycée," Sticef, vol. 21, pp. 651-665, 2014. URL:http://sticef.univ-lemans.fr/num/vol2014/23r-fa illet/sticef_2014_faillet_23rp.pdf

[15] J. L. Bishop and M. Verleger, "The flipped classroom: A survey of the research," presented at the the 120th ASEE Annual Conference and Exposition, Atlanta, GA, June 2013, pp. 1-18. URL: https://www.asee.org/public/conferences/20 /papers/6219/download

[16] L. Lahaye, "Flipped Classroom ou classe inversée... Une autre manière d'enseigner avec le numérique," Analyse UFAPEC, vol. 34, no. 14, pp. 1-8, 2014. URL: https://tinyurl.com/y6bpuy25

[17] M. Lebrun, "La classe inversée au confluent de différentes tendances dans un contexte mouvant," in La pédagogie inversée: Enseigner autrement dans le supérieur par la classe inversée, A. Dumont and D. Berthiaume Eds., 1re ed. Louvain-La-Neuve: De Boeck supérieur, 2016, ch. 1, pp. 13-38.

[18] L. W. Johnson and J. D. Renner, "Effect of the flipped classroom model on a secondary computer applications course: student and teacher perceptions, questions and student achievement," $\mathrm{PhD}$, Department of Leadership, Foundations \& Human Resource Education, University of Louisville, Louisville, Kentucky, 2012.

[19] M. J. Lage, G. J. Platt, and M. Treglia, "Inverting the classroom: A gateway to creating an inclusive learning environment," The Journal of Economic Education, vol. 31, no. 1 , pp. 30-43, 2000. DOI: 10.1080/00220480009596759

[20] J. Bergmann and A. Sams, "Remixing Chemistry Class," Learning \& Leading With Technology, vol. 36, no. 4, pp. 22-27, 2009. URL: http://files.eric.ed.gov/fulltext/EJ90429 $0 . p d f$

[21] S. Bissonnette and C. Gauthier, "Faire la classe à l'endroit ou à l'envers ?," Formation et profession, vol. 20, no. 1, pp. 23-28, 2012. doi : 10.18162/fp.2012.173

[22] Khan, S., "Let's use video to reinvent education", TED, 2011. URL:

https://www.ted.com/talks/sal_khan_let_s_use_video_to_re invent_education?language $=\mathrm{en}$

[23] T. Green, "Flipped Classrooms: An Agenda for Innovative Marketing Education in the Digital Era," Marketing Education Review, vol. 25, no. 3, pp. 179-191, 2015/09/02 2015, doi: 10.1080/10528008.2015.1044851.

[24] M. Baumard. "Privé d'école, l’Afrique francophone parie sur la Khan Academy et son enseignement des sciences." Le 
Monde.

https://www.lemonde.fr/afrique/article/2020/03/30/prive-decole-l-afrique-francophone-parie-sur-la-khan-academy-et-s on-enseignement-des-sciences_6034939_3212.html (accessed 30/03/2020.

[25] I. Nizet, "Préface," in La classe inversée, J. Bergmann and A. Sams Eds. Québec: Editions Reynald Goulet inc., 2014, ch. Préface, pp. vii-x.

[26] A. Tricot. Engagement des élèves dans les apprentissages sur les temps scolaires : rôle de l'accompagnement personnalisé. http://www.ac-bordeaux.fr/cid101368/conference-andre-tric ot-mars-2016.html (Accessed 06/08/2020).

[27] M. T. Chi, "Active-constructive-interactive: a conceptual framework for differentiating learning activities," Top Cogn Sci, vol. 1, no. 1, pp. 73-105, Jan 2009, doi: 10.1111/j.1756-8765.2008.01005.x.

[28] MEN [Ministère de l'éducation nationale]. Cadre de référence de l'examen national du baccalauréat. pp. 1-25, 2015.

URL:https://www.men.gov.ma/Ar/Documents/N123151104 .pdf

[29] M. Guilbault and A. Viau-Guay, "La classe inversée comme approche pédagogique en enseignement supérieur : état des connaissances scientifiques et recommandations," Revue internationale de pédagogie de l'enseignement supérieur vol. 33, no. 1, 2017. URL : http://journals.openedition.org/r ipes/1193

[30] J. L. Dobson, "The use of formative online quizzes to enhance class preparation and scores on summative exams," (in eng), Adv Physiol Educ, vol. 32, no. 4, pp. 297-302, Dec 2008, doi: 10.1152/advan.90162.2008.

[31] F. Shannon and G. Greg, "Using Lean in the Flipped Classroom for At Risk Students," Journal of Educational Technology \& Society, vol. 16, no. 1, pp. 356-366, 2013.

[32] M. Forsey, M. Low, and D. Glance, "Flipping the sociology classroom: Towards a practice of online pedagogy," Journal of Sociology, vol. 49, no. 4, pp. 471-485, 2013, doi: $10.1177 / 1440783313504059$.

[33] K. Fulton, "Upside down and inside out: Flip Your Classroom to Improve Student Learning," Learning and leading with technology, vol. 39, pp. 12-17, 2012. URL: http://files.eric.ed.gov/fulltext/EJ982840.pdf

[34] G. S. Mason, T. R. Shuman, and K. E. Cook, "Comparing the Effectiveness of an Inverted Classroom to a Traditional Classroom in an Upper-Division Engineering Course," IEEE Transactions on Education, vol. 56, no. 4, pp. 430-435, 2013, doi: 10.1109/TE.2013.2249066.

[35] J. E. McLaughlin et al., "The flipped classroom: a course redesign to foster learning and engagement in a health professions school," (in eng), Acad Med, vol. 89, no. 2, pp. 236-43, Feb 2014, doi: 10.1097/acm.0000000000000086.

[36] R. Pierce, "Student Performance in a Flipped Class Module," In R. McBride \& M. Searson (Eds.), Proceedings of SITE 2013--Society for Information Technology \& Teacher Education International Conference, New Orleans, Louisiana, USA, Mar., 2013, pp. 942-954. URL: https://www.learntechlib.org/p/48235.

[37] S. G. Wilson, "The Flipped Class: A Method to Address the
Challenges of an Undergraduate Statistics Course," Teaching of Psychology, vol. 40, no. 3, pp. 193-199, 2013/07/01 2013, doi: 10.1177/0098628313487461.

[38] R. Pierce and J. Fox, "Vodcasts and active-learning exercises in a "flipped classroom" model of a renal pharmacotherapy module," American journal of pharmaceutical education, vol. 76, no. 10, pp. 196-196, 2012, doi: 10.5688/ajpe7610196.

[39] E. Choi, "Applying Inverted Classroom to Software Engineering Education," IJEEEE, vol. 3, no. 2, pp. 121-125, 2013, doi: 10.7763/ijeeee.2013.v3.205.

[40] R. S. Davies, D. L. Dean, and N. Ball, "Flipping the classroom and instructional technology integration in a college-level information systems spreadsheet course," Educational Technology Research and Development, vol. 61, no. 4, pp. 563-580, 2013, doi: 10.1007/s11423-013-9305-6.

[41] B. Love, A. Hodge, N. Grandgenett, and A. W. Swift, "Student learning and perceptions in a flipped linear algebra course," International Journal of Mathematical Education in Science and Technology, vol. 45, no. 3, pp. 317-324, 2014, doi: 10.1080/0020739X.2013.822582.

[42] T. Lucke, U. Keyssner, and P. Dunn, "The use of a Classroom Response System to more effectively flip the classroom," the 2013 IEEE Frontiers in Education Conference (FIE), Oklahoma City, USA, pp. 23-26, DOI: 10.1109/FIE.2013.6684872

[43] J. S. Jeong, D. González-Gómez, and F. Cañada-Cañada, "Students' Perceptions and Emotions Toward Learning in a Flipped General Science Classroom," Journal of Science Education and Technology, vol. 25, no. 5, pp. 747-758, 2016, doi: 10.1007/s10956-016-9630-8.

[44] S. Al-Hebaishi, "Using the flipped classroom model to enhance problem-based learning in a practicum course," International Journal of Technology Enhanced Learning, vol. 10, no. 4, pp. 329-344, 2018, doi: 10.1504/IJTEL.2018. 095143.

[45] S. Anbalagan and J. Jayachithra, "Satisfaction Of Flipped Classroom Teaching Strategies Among B.Ed Teacher Trainees," International Journal of Scientific \& Technology Research, vol. 9, pp. 5196-5198, 2020, URL: https://tinyurl.com/y3wwsbv7

[46] D. González-Gómez, J. S. Jeong, F. Cañada-Cañada, and A. Gallego Picó, "La enseñanza de contenidos científicos a través de un modelo «Flipped»: propuesta de instrucción para estudiantes del Grado de Educación Primaria," Enseñanza de las Ciencias. Revista de investigación y experiencias didácticas, vol. 35, no. 2, pp. 71-87, 2017, doi: 10.5565/rev/ensciencias.2233.

[47] W. Shadish, T. Cook, and D. Campbell, "Experiment and Generalized Causal Inference," in Experimental and Quasi-Experimental Designs for Generalized Causal Inference, T. C. W.Shadish, \& D. Campbell Ed., 2 ed. Boston: Houghton Mifflin Company, 2002, ch. 1, p. 623.

[48] L. J. Cronbach, "Coefficient alpha and the internal structure of tests," Psychometrika, no. 16, pp. 297-334, 1951, https://doi.org/10.1007/BF02310555

[49] J. M. Cortina, "What is coefficient alpha? An examination of theory and applications," Journal of applied psychology, vol. 
78, no. 1, pp. 98-104, 1993, https://doi.org/10.1037/0021-90 10.78.1.98

[50] J. D. Brown, "The Cronbach alpha reliability estimate," Shiken: JALT Testing \& Evaluation SIG Newsletter, vol. 6, no. 1, pp. 17-19, 2002. URL: http://jalt.org/test/PDF/Brown 13.pdf

[51] R. F. DeVellis, Scale Development: Theory and Applications, 3 ed. Thousand Oaks, CA: Sage Publications, 2012.

[52] J. Cohen, Statistical Power Analysis for the Behavioral Sciences. L. Erlbaum Associates, 1988.

[53] N. O. AbuZaherah, "The Effect of Using Integrated
Education on Cognitive Achievement and Survival of the Effect of Learning for First Year Secondary School Students in Chemistry," Journal of Educational and Psychological Sciences vol. 4, no. 16, pp. 154 - 168, 2020, doi: https://doi.org/10.26389/AJSRP.D111119.

[54] J. D. Karpicke and H. L. Roediger, "The critical importance of retrieval for learning," Science, vol. 319, no. 5865, pp. 966-8, 2008, doi: 10.1126/science.1152408.

[55] A. Bouvier. "COVID19: il faut préparer le monde pédagogique post crise." mission laïque française. https://www.mlfmonde.org/tribunes/covid19-il-faut-prepare r-le-monde-pedagogique-post-crise/\#_ftn3 (accessed 17/06/2020). 